\title{
Merging different interactivity perspectives 1.0 and 2.0 frameworks
}

\section{Combinando diferentes perspectivas de interatividade}

Estruturas 1.0 e 2.0

Gabriella Taddeo*

\begin{abstract}
My aim in this paper is to present an analysis of the concept of audiovisual interactivity and its evolution in relation to web 2.0 and participatory culture. A brief theoretical framework on the concept of interactivity and its evolutions in the last decades will be followed by an analysis of the traditional interactivity concept based on a closed user-medium relationship. Finally, I will further articulate my reflection on new forms of interactivity which are based on a more participatory model in which users interact among themselves and create communities within and through interactive media environments. Using Thompson's theoretical framework (1995) on media interaction, my attempt will be to define how new participative strategies of $2.0 \mathrm{tv}$ are creating not only new forms of contents and languages, but also "mediated-quasi interactions" between media producers and their audience. These environments are thus characterized by an indirect dialogue and a complex competition for media imaginary dominance.

Keywords: Interactivity; Participation; Active audiences; Mediated quasi-interaction; New media literacy
\end{abstract}

Resumo: Meu objetivo neste trabalho é apresentar uma análise do conceito de interatividade audiovisual e sua evolução em relação à web 2.0 e à cultura participativa. Um breve referencial teórico sobre o conceito de interatividade e sua evolução nas últimas décadas será seguido por uma análise do conceito tradicional de interatividade baseado em uma relação usuário-meio fechada. Ao final vou ainda articular a minha reflexão sobre novas formas de interatividade que se baseiam em um modelo mais participativo no qual os usuários interagem entre si e criam comunidades dentro e através dos ambientes de mídia interativos. Utilizando o referencial teórico de Thompson (1995) sobre interação mediada, meu objetivo será definir como novas estratégias participativas da TV 2.0 estão criando não apenas novas formas de conteúdo e de linguagem, como também "interações quase-mediadas" entre produtores de mídia e seu público. Esses ambientes são, então, caracterizados por um diálogo indireto e uma complexa competição para o domínio do imaginário midiático.

Palavras-chave: Interatividade; Participação; Público ativo; Interação quase-mediada; Alfabetização em novas mídias

* Ph. D., lecturer, Dicas: Department-Faculty of Architecture, Polytechnic of Turin, Italy; e-mail: gabriella.taddeo@polito.it

\begin{tabular}{|c|c|c|c|c|c|}
\hline Civitas & Porto Alegre & v. 9 & n. 1 & p. 133-148 & jan.-abr. 2009 \\
\hline
\end{tabular}




\section{Introduction}

Interactivity has been defined in various fields from different perspectives. My aim in this paper is to present an analysis of the concept of audiovisual interactivity and its evolution in relation to web 2.0 and participatory culture (Jenkins, 2006).

As I shall try to outline further on, this evolution is producing not only new fruition models but also new forms of media businesses, new practices and relations between media producers and their audience.

With this goal in mind, the starting point of the present paper will be a brief theoretical framework on the concept of interactivity and its evolutions in the recent years, which will be followed by an analysis of the more traditional interactivity concepts based on a closed user-medium relationship.

Finally, the focus will be set on new forms of interactivity, based on a more participatory model in which users interact amongst themselves and create communities within and through interactive media environments. My intention is to demonstrate that this second type of interactivity, which breaks up mainstream production models and traditions to a higher extent, is actually the most promising, as it offers a new spectator model and creates an innovative, bidirectional dialogue channel between media and their audience.

\section{What is interactivity: a brief theoretical recognition}

Following Rafaeli's and Ariel's analysis (2007) we can consider three distinct interactivity definition frameworks:

- Interactivity as a process related variable (process oriented interactivity)

- Interactivity as an invariable medium characteristic (medium oriented interactivity)

- Interactivity as a perception-related variable (user oriented interactivity)

Considering process-oriented interactivity, we can refer to Rafaeli's classical definition of interactivity: "The extent to which messages in a sequence relate to each other and especially the extent to which later messages recount the relatedness of earlier messages." Many media analysts, from the media industry and media production in particular (Markus 1990; Rust; Varki, 1996; Sundar, 2004), interpreted interactivity as a medium property and proposed a media-oriented interactivity definition, focusing on technological media features and their ability to generate activity. 
Furthermore, we can consider a user-oriented definition framework. For instance, Wu (1999), Newhagen (2004), and many others, studied interactivity as a perception related variable focused on users' experiences and selfreports.

Considering 2.0 web tendencies and the new media industry, it is evident that the three abovementioned definition areas are presently not easily distinguishable: in fact, considering, for example, the You Tube case study, we can suppose that medium features as, for example, easy and usable methods and interfaces to upload videos, have promoted individual processes of self expression and narration, which consequently created and stimulated viral and social processes of life sharing, together with empathy and community.

Figure 1: Outiline of Youtube interactive processes throughout medium properties, individual and social interactive uses

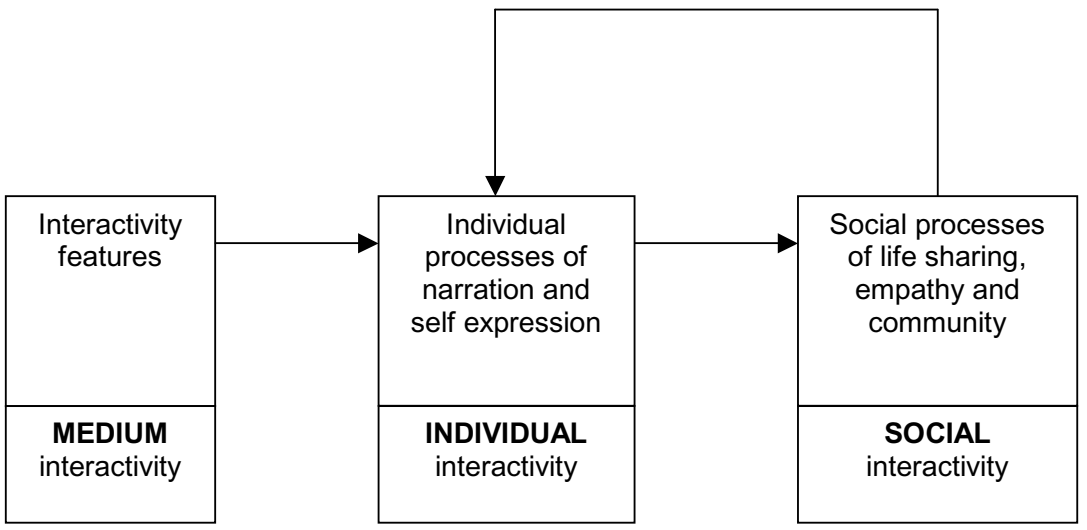

In this case in particular, a substantial medium porosity, intended as the medium openness to user contribution and modelling, has allowed the emergence of new forms of self-recognition and narration, also creating new cultural tools and languages for the performance and socialization of user's own subjectivity

As the anthropologist Wesch (2008) underlined, through an empirical analysis of YouTube's production, users passed to new media fruition forms, shifting from individualism to communitarism, from independence to relationship, and, in my opinion, also from a closed interactivity concept to a more open and socialized one. These practices allow us to understand to a 
higher extent media use from a transformative point of view which erases the division between production and consumption of cultural products, thus redefining the role of the audience.

In the next paragraph, we can explore how, in the last few years, media producers experimented individualized interactivity using interactive features to personalize media contents and experience. As Fornäs et al. (2002, p. 23) noticed, "... recent digital technologies have radically enhanced these kinds of interactivity by explicitly emphasizing the user's response and active assistance in the formation of the media text itself and by developing particular tools to facilitate this."

In this framework, many interactive tv products that attempt to disrupt mass media logic and create a prosumer (Toffler, 1980) have been created for the benefit of a user/producer that can deeply personalize his/her media fruition experience.

As many authors recently remarked (Manovich, 2001; Bolter; Grusin, 2000), such interactivity processes have involved many changes not only in the production and distribution fields (e.g. the use of many more distribution platforms and cross medial interactive strategy and marketing promotion), but also in the aesthetics and in media languages (e.g. new experimental media practices, hypermedial narration, convergence and integration of codes).

Nevertheless, these new interactive languages did not really substitute classical fruition models, and, in particular, they did not really trigger domestication processes (Silverstone; Haddon, 1996) through which audience was deeply and actively involved in media construction.

Many analysis (as in Taddeo, 2007) state that, despite an increasing "interactive philosophy" in the media industry and in the intellectual environments, people have not yet really been engaged in this type of audiovisual interactivity present in enhanced tv projects, digital terrestrial tv applications, tv commerce and tv banking, and in many other experimental projects carried out recently.

For this reason, paralleling this interactive approach, in which the control and the editorial supervision of mainstream media producers is still strong, we will consider another emergent interactive approach, defined by Marshall (2004) as a "writerly approach" to the study of new media, more focused on the engagement in practices of cultural production in opposition to the traditional "readerly" approach.

In this scenario: “ $\ldots$ as the industry grapples with this new paradigm through copyright and intellectual property debates, new media users continue 
to encroach on appropriating and making their cultural forms their own" (Marshall, 2004, p. 11).

By comparing these two different strategies on interactivity, I will try to gain insight into the new balances between traditional media subjects (e. g. editors, directors, media marketing operators) and common people, also defined as media outsiders (Ricciardi, 2008), and I will seek to outline the new "imaginary arena" that these actors have been creating.

\section{The 1.0 interactivity framework: a user-medium model}

As stated above, we can presently consider two main paradigms of audiovisual interactive products: the first one is more centred on a strict relation and feedback between user and product, the second, on the contrary, is focused on a relation among users, carried out through the audiovisual product.

As for the first interactivity typology, a highly interesting product taxonomy proposed by Favre (2001) can be adopted.

The following different interactive audiovisual formats can be outlined from his analysis:

- Enhanced video

- Nodal video

- Parallel video

- Multipath video

- Multimodal video

- Algorithmic video

\section{Enhanced video}

In this first type of media products, interactive features do not break the linear flow of video contents. Interactive elements - as, for example, quizzes, games, betting and additional information - are simply overlapped to traditional contents, they are independent and they do not really change the original meaning, the programme scheduling and the formal video structure.

This kind of interactivity is typical, for example, of digital terrestrial tv.

\section{Nodal video}

In the nodal interactivity type, users can enjoy a linear storytelling that offers several interactive segments, called nodes, along its course. During the fruition of such nodes, viewers cease to be passive and are asked to interact with the story, in predefined moments, without changing it in any way. 
This type of interactivity, in comparison with the enhanced model, allows the viewer to stop the linear narrative contents flow and to "freeze" the story until she/he has solved the interactive situation.

Several excellent examples of this interactivity in many DVD special contents can be mentioned, as, for example the famous Harry Potter: the chamber of secrets (2002).

In broadcast programs this interaction is not really possible because a stopping action conflicts with the linear broadcasting transmission flow. Despite this, since the beginning of tv, there have been several highly interesting and well-known experimental products, such as Winky Dink (1953), an interactive cartoon based on a "magic drawing screen", which was a large piece of plastic which held on the television screen via static electricity. In every Winky Dink episode, Winky arrived upon a scene which contained a "connect the dot" picture. Hence, he prompted children at home to complete the picture, using the dedicated drawing kit: the finished result of the viewer's interaction would help him to continue the story.

Therefore, as we can imagine, in the nodal interactivity the narrative structure is pre-modelled and it keeps its course even if viewers do not interact with the video. For this reason we can consider this type interactivity a simulation.

\section{Parallel video}

The parallel interactivity model allows people to watch the programme simultaneously from different points of view. In particular:

- Character based points of view: for instance viewers can follow the story choosing a specific character's point of view;

- Location based points of view: as in many sport programs, viewers can follow the match from different camera angles.

An interesting example of this interactivity type is indeed D-Dag (1999), a character based interactive story which was broadcasted in four parallel channels.

In D-Dag, different Danish television channels were on air at the same time, with four different movies, each shot by a different director. Each director had one main character, and one camera team that followed this person. The four movies lasted 70 minutes and were broadcasted on the $1^{\text {st }}$ January 2000. Each viewer was supposed to edit his/her own version, from the four movies running simultaneously, using the remote control as an editing device. Despite the fact that the plot was the same for all movies - which involved four people who planned to rob a bank, using the noise arising from new 
year's eve celebrations to conceal the explosion- each viewer saw a different movie.

\section{Multipath video}

This type of interactivity has a typical hypertextual structure in which viewers are asked, in some narration points, to choose their own path within the narration by using their remote control.

Contrary to the parallel model, in this case there are no different parallel stories, but a unique story which is developed linearly by each viewer via a multiple choice process.

This type of interactivity needs, in broadcast productions, multiple feeds to allow one-to-one interaction; thus it consequently turns out to be a very expensive production.

An important experimentation, running 24 hours a day in digital satellite and terrestrial tv, was BBCI - Pyramid challenge - the book of buried pearls (2002). It was, according to the producers, "the world's first interactive TV adventure story". The programme involved the switching of four separate video feeds so that the viewers could choose their own path during the course of this adventure using their remote control.

The narrative of the show encouraged viewers to use their powers of observation and common sense to guide the protagonist through a series of challenging situations in modern day Egypt.

The programme described a journey from London to Saqqara where the pyramid was invented, as well as to the Great pyramid at Giza. There, viewers faced their final challenge of unlocking the pharaoh's hidden chamber.

If the right path was selected by the viewer (by choosing the correct video streams) he/she was awarded a number which was a part of a secret code necessary to unlock a tomb and have the chance to win a holiday to Egypt.

\section{Multimodal video}

Nowadays, multimodal interactivity is often used to empower and innovate audiovisual contents, building a modular structure that does not revolutionize their traditional narrative strategies nor their organizational and production models.

In this interactivity model, the authors tell a story across a puzzle of contents, suggestions and emotional connotations that viewers have to compose by picking from a collection of media. 
Usually, many media are used and combined to create a multimodal narrative experience: a TV program, a web site, a mobile phone service, an email campaign, the press, advertising, and often also postcards, fax, billboards, etc.

Nevertheless, not all media need to be interactive.

We can consider as an interesting example of this interactivity the Australian production of Fat cow motel (2003).

In this 13-part drama series, each episode ended with a cliff hanger mystery that the audience could solve by paying particular attention during the programme or looking for additional clues when interacting with the show online, via email, SMS, voicemail or via interactive TV.

In fact, the more platforms the viewers used to interact with the show, the more clues they received.

For instance, by visiting the Fat cow motel website, ${ }^{1}$ viewers could obtain additional clues reading the local newspaper "The Fat Cow Bugle" or getting involved in the characters' lives and intercepting their email, voicemail and guest-book entries.

Viewers could also register to have SMS messages sent to their mobile phones and receive messages that regular TV viewers could not obtain.

Two versions of the $13^{\text {th }}$ final episode were filmed and allowed viewers to vote online and via SMS how they wanted the series to end.

ABC's Fat cow motel website has become the most visited television related-website in ABC Online's seven year history, receiving an outstanding record of 1,182,570 page impressions in the program's second week on air.

At present, all the most important series, sit-com, films and musical events are coupled with their dedicated cross-media environments that massively contribute to create their marketing strategies and to build accurate customer loyalty promotion strategies.

\section{Algorithmic video}

Algorithmic interactivity is not pre-planned (nor written) by the authors but it is self-generated in real time from the viewers' performance as they interact with narrative material or with each other.

It is composed of a set of rules or principles, implemented in digital scripts, rather than narrative elements or characters. For this reason, it presents a generative structure which is the most open interactivity model proposed up to date.

\footnotetext{
1 http://www.fatcowmotel.com.au. (last visited on January 9, 2009).
} 
A significant example in this area can be considered the Façade (20052008) project.

As described in its official web site $^{2}$, Façade is an artificial intelligencebased art/research experiment in electronic narrative. It is clearly an attempt to step beyond traditional branching or hyperlinked narrative to create a fully realized, one-act interactive drama. Integrating an interdisciplinary set of artistic practices and artificial intelligence technologies, it has implicated a five year collaboration to design a novel architecture for supporting emotional, interactive character behaviour and drama-managed plot. Within this architecture authors have built a 3D virtual real-time world inhabited by computer-controlled characters, in which the player experiences a story from a first-person perspective.

The user interaction is described in the project as follows:

[...] you, the player, using your own name and gender, play the character of a longtime friend of Grace and Trip, an attractive and materially successful couple in their early thirties. During an evening get-together at their apartment that quickly turns ugly, you become entangled in the high-conflict dissolution of Grace and Trip's marriage. No one is safe as the accusations fly, sides are taken and irreversible decisions are forced to be made. By the end of this intense one-act play you will have changed the course of Grace and Trip's lives - motivating you to re-play the drama to find out how your interaction could make things turn out differently the next time. ${ }^{3}$

\section{Limits of the 1.0 interactivity model and the need to overcome it}

As analysed above, many experimental projects have been developed in recent years in order to involve viewers more and more intensively in the text and to allow them to further define their specific media experience.

In this framework, we can summarize that, following Toffler's (1980) analysis, viewers became pro-sumers: consumers that can produce their own text by directly interacting with it and changing formal aspects, sequence, elements order and also logic and narrative structure.

The power of choice, firstly implemented by remote control, secondly powered by personal video recording and TIVO (a standalone TVR that

2 Façade was publicly released as a freeware download/cd-rom in July 2005. It is now available on line: http://www.interactivestory.net/ (last visited on January 9, 2009).

3 Source: http://www.interactivestory.net/\#facade (last visited on January 9, 2009). 
allows viewers to record TV programs via satellite, cable or antenna, hosting an extensive set of functions ${ }^{4}$ ), and now, as we have seen, augmented with hypermedial features, is, in this model, the key factor to offer viewers a more engaging and involving media experience.

Nevertheless, as evident in all the examples mentioned herein, these interactivity models present a strictly closed user-medium interaction, which offers a unidimensional paradigm of cultural meaning building and underestimates the social dimension of television as a cultural environment in which not only meanings are exchanged between user and medium, but discourses and relationships are also created and culture is socialized by sharing languages, contents, media myths and imaginary among people.

It is an interactivity that, as Sonia Livingstone (Livingstone, 2005) underlined, keeps a traditional interpretation frame of the audience's behaviours, simply transforming viewers in users, borrowing the conceptualization from the computer science, but adopting a term that is anyhow "... surely equally unsatisfactory for the breadth and depth of meanings required, for it lacks any direct relation to communication in particular, and it implies an instrumental individualism rather than a collective, even public, status."

For this reason, more recently, critical audience studies are migrating into intellectual inquiry focused on participation, thus developing stress on processes of engagement, generating analyses of user-generated content, fan creativity, citizens' media, and new and dispersed forms of audience interactivity.

We can define this passage as an overcoming of the 1.0 interactivity paradigm and an approach, theoretical and practical, to a 2.0 interactivity concept, in which the participative, bottom-up, communitarians, dialogical and social shaping of media are stressed and gain further importance.

\section{The 2.0 interactivity framework: a participatory model}

H. Jenkins' contribution in this second practical and theoretical framework is a key element for the analysis of the matter in hand.

The author, in fact, proposes to distinguish interactivity from participation.

In particular, according to him interactivity is related to: “... the ways that new technologies have been designed to be more responsive to consumer feedback".

\footnotetext{
4 For further informations visit: www.tivo.com (last visited on January 9, 2009).
} 
Participation, on the other hand, is shaped more from social and cultural protocols.

Following another author's example, the amount of conversation in a cinema theatre, that can be considered an authentic participation instance, is determined more by subculture tolerance or national contexts than by an innate property of cinema itself.

In opposition to the 1.0 framework, we can define the participation as a "2.0 interactivity", thus borrowing the term from the new media language and focusing on the acceleration of participation processes shaped by $2.0 \mathrm{web}$ tools as social networks, wikis, blogs and other digital environments.

Different 2.0 interactive tv forms are defined below:

- dialogue among users about media contents (e.g. chat tv)

- self-expression (e.g. user generated content tv)

The first form is already common in many tv programs also in the broadcast world: we can consider, for example, numerous MTV music programs that allow viewers to write, via SMS or web, a message that is broadcasted and overlapped to the videoclip. Using these functions young people often create a para-discourse on the videoclip, or also far from it, switching from a private discourse level to a broader and visible one.

The second 2.0 interactivity form is rising only with web tv and with the emergence of 2.0 web tools.

Such model merges traditional contents - created by an editorial board according to classical media market rules - with bottom-up contents produced by people.

In Italy, despite the conservatory system of the tv market in the analogical field, there are many pioneering experiences and several web "viewer generated contents tvs" are constantly increasing.

For example, Nessuno tv, ${ }^{5}$ Qoob tv, ${ }^{6} \mathrm{Yks} \mathrm{tv}^{7}$ and Current Italia tv ${ }^{8}$ are based on user generated contents scheduling programs, and many of them have not only a web distribution but also broadcast diffusion.

Therefore, the different interactivity dynamics that this new audience participation creates can now be described.

It is indeed useful to start from Thompson's classical theory (1995) on relations and interactions transformations produced by media.

\footnotetext{
http://www.redtv.it/ (last visited on January 9, 2009).

http://it.qoob.tv/ (last visited on January 9, 2009).

http://www.tbtv.it/homepage.xsp (last visited on January 9, 2009).

www.current.tv/ (last visited on January 9, 2009).
} 
According to the author, three forms of interaction among human beings are important:

- face-to-face interaction;

- mediated interaction;

- mediated quasi-interaction.

In face-to-face interaction, people communicate sharing time and space, since they are co-present.

In mediated interaction, the sending of the message and its reception are separated in time and space. The media moreover co-shapes the message.

As mediated interaction, mediated quasi-interaction stretches information in time and space and it differs from the former as there are no recipients defined beforehand. A telephone conversation or an e-mail exchange between two or more people is a form of mediated interaction.

Mass media such as television, radio and newspapers create instances of mediated quasi-interaction.

In fact, as Thompson says $(1985$, p. 84$)$

[...] since mediated quasi interaction is monological in character and involves the production of symbolic forms for an indefinite range of potential recipients, it is best regarded as a kind of quasi interaction. It doesn't have the degree of reciprocity and interpersonal specificity of other forms of interactivity, whether mediated or face to face. But mediated quasi interaction is, none the less, a form of interaction. It creates a certain kind of social situation in which individuals are linked together in a process of communication and symbolic exchange. It is a structured situation in which some individuals are engaged primarily in producing symbolic forms for others who are not physically present, while others are involved primarily in receiving symbolic forms produced by others to whom they cannot respond, but with whom they can form bonds of friendship, affection and loyalty.

Applying this distinction to our examples of participatory tv we can find in them a mixed expression of mediated and quasi-mediated interaction.

In fact, in this tv, people can make conversation about media contents by using chats, forums, and other synchronous and asynchronous communication tools, developing mediated interactions.

Nevertheless, they can also produce personal contents which are distributed in the global channel of internet and often also in broadcast tv channels: hence, they develop instances of mediated quasi-interaction delivering their contents to unknown recipients and addressing their messages to an imaginary audience. 
By generating contents, people not only are allowed to create an active reception experience (as in the 1.0 interactive perspective), but they are also allowed to quasi-interact with media industry contributing to social and cultural shaping of media imaginary.

In fact, there is a constant mediated quasi-interaction between mainstream media producers, which look at user generated contents for marketing analysis and prototyping, and their fans, an active audience which continuously acquires mainstream contents and re-elaborates them through 2.0 web tools.

Figure 2: A 2.0 interactivity media model

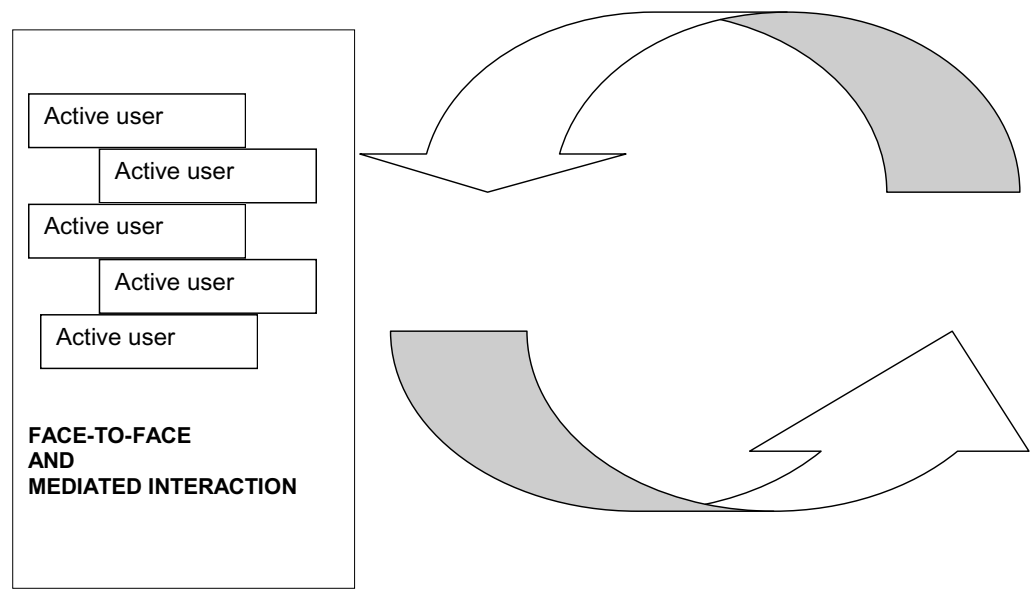

In the new participative tv platforms people often interact amongst themselves, using mediated communication tools, in order to create, deliver and evaluate their own contents. Furthermore, they also indirectly communicate with the media industry, proposing new contents, languages, stylistic forms and explicitly competing with it for the media imaginary building.

Is the grassroot logic of user generated contents similar, in conflict or integrated with mainstream media contents?

Which relationships are being shaped between new active audiences and the cultural industry?

At present, it is difficult to make any forecast or to give a definite response.

The rise and the promotion of a participation media model is much more provoking and revolutionary, for media industries, than a simple "1.0 interactivity" policy. 
As a matter of fact, allowing people to interact with contents in controlled circumstances is one thing, allowing them to participate to the construction and distribution of media products, in their terms, is something else altogether.

For these reasons, as Jenkins underlines, many media majors have strongly struggled against audience participation to their products and have considered it as a "invasion of the public", an illegitimate copyright violation, ultimately an intrusion in their "text vineyard". 9

In Italy too, some debates in web forums (e.g. Current tv Italia forum $)^{10}$ show that the participation culture of 2.0 users is not totally accepted and integrated with the media industry's rules and paradigms.

Nevertheless, more recently, we notice an inverse tendency: the most innovative mainstream producers, mostly coming from ICT industry, are beginning to understand that the ability to create and to manage people participation in their media products can become much more profitable than a simple 1.0 interaction strategy.

In fact, if a 1.0 interaction can lengthen the consumption time, create consumer loyalty and at the least improve user gratification and experience, media industries can really empower viral processes of social diffusion and cultural epidemics of their products only through 2.0 interactivity strategies.

In other words, people and media producers are still arguing about interactivity boundaries, limits and about the possibility that interactivity could really switch from a 1.0 to a 2.0 paradigm, intended as a deeper form of audience participation. They are also creating new "literacy" practices to learn to manage each other's mediated quasi-interaction and to use it as a vehicle for a new cultural experience.

9 The term is borrowed from the famous work of Illich In the vineyard of the text (1994) in which the author explores how revolutions in technology affect the way we read and understand texts. For a deeper description and further analyses of the struggles between media majors and their audiences, in particular the most active and participatory fans, refer to Convergence Culture (Jenkins 2006).

${ }^{10} \mathrm{I}$ have recognised the dynamics and relation between active users and Current editorial staff through a content analysis of Current tv web forum. The analysis was carried out on all messages posted in the forum from May to September 2008. Current Italia was indeed a highly interesting case study. It was launched in May 2008 and the recently "born" audience community had intense discussions about the role of users in the new tv, their level of acceptance of mainstream tv rules and, on the other hand, on their expectations to propose, as users, formats, contents and divergent points of view. 


\section{References}

BOLTER Jay David; GRUSIN Richard. Remediation: understanding new media. Boston: MIT Press, 2000.

FAVRE, Julien. Fiction interactive: quels formats? Dossiers de l'audiovisuel, v. 92, p. 53-55, 2000.

FORNÄS, Johan et al. Into digital borderlands. In: FORNÄS, Johan et al. (eds.). Digital borderlands. New York: Peter Lang, 2002, p. 1-47.

JENKINS, Henry. Convergence culture: where old and new media collide. New York: New York University Press, 2006.

ILLICH, Ivan. In the vineyard of the text: a commentary to Hugh's Didascalicon. Chicago: University of Chicago Press, 1996.

LIVINGSTONE, Sonia. Engaging with media - a matter of literacy? Keynote presentation to the conference Transforming audiences: identity/creativity/everyday life. Westminster: September 2007.

MANOVICH, Lev. The language of new media. Boston: MIT Press, 2001.

MARKUS, M. Lynne. Toward a "critical mass" theory of interactive media. In: FULK, Janet; STEINFELD, Charles William (eds.). Organization and communication technology. Newbury Park: Sage, 1990, p. 194-218.

MARSHALL, David P. New media cultures. London: Arnold, 2004.

NEWHAGEN, John. Interactivity, dynamic symbol processing and the emergence of content in human communication. Information Society, London, v. 20, n. 5 , p. 395-400, 2004.

RAFAELI, Sheizaf. Interacting with media: para-social interaction and real interaction. Unpublished doctoral dissertation, Stanford: Stanford University, 1985.

RAFAELI, Sheizaf; ARIEL, Yaron. Assessing interactivity in computer-mediated research. In: JOINSON, Adam et al. (eds.). The Oxford handbook of internet Psychology. Oxford: Oxford University Press, Chapter 6, 2007, p. 71-88.

RAFAELI, Sheizaf; SUDWEEKS, Fay. Networked interactivity. Journal of ComputerMediated Communication, v. 2 n. 4, 1997.

RICCIARDI, Mario. Il museo dei miracoli, Milano: Apogeo, 2008.

RUST, Roland; VARKI, Sajeev. Rising from the ashes of advertising. Journal of Business Research v. 37, n. 7, p. 173-181, Nov. 1996.

SILVERSTONE, Roger; HADDON, Leslie. Design and the domestication of information and communication technologies: technical change and everyday life. In: MANSELL, Robin; SILVERSTONE, Roger (eds.). Communication by design: the politics of information and communication technologies. New York: Oxford University Press, 1996, p. 44-74.

SUNDAR, S. Shyam. Theorizing interactivity's effects. Information Society, v. 20 n. 5, p. 385-389, Nov. 2004. 
TADDEO, Gabriella. Ipercinema: l'immaginario cinematografico nell'era digitale. Milano: Guerini e Associati, 2007.

TOFFLER, Alvin. The third wave. New York: Bantam, 1980.

THOMPSON, John B. The media and modernity: a social theory of media. Cambridge: Polity Press, 1995.

WESCH, Michael. An anthropological introduction to YouTube. Video documentary presented at the Library of Congress, June 23rd 2008. Disposable at the site ttp://www. youtube.com/watch?v=TPAO-1Z4_hU. (last visited on January 9, 2009).

WU, Guohua. Perceived interactivity and attitude toward website. Paper presented at the American Academy of Advertising annual conference, Albuquerque, 1999.

Received Jan. 10, 2009

Approved Apr. 29, 2009 